\title{
IMPLEMENTASI ALGORITMA PARTITIONING AROUND MEDOIDS DALAM PENGELOMPOKAN RESTORAN
}

\author{
Tito Bimantoro' ${ }^{1}$, Anindya Khrisna Wardhani² \\ ${ }^{1}$ Universitas Dian Nuswantoro, ${ }^{2}$ Universitas Diponegoro \\ Email: ${ }^{1}$ bimantoro25@gmail.com, ${ }^{2}$ nindywardhani77@gmail.com
}

(Naskah masuk: 10 Desember 2020, diterima untuk diterbitkan: 29 Desember 2020)

\begin{abstract}
Abstrak
Banyaknya data yang hanya sebatas memberikan grafik atau statistik mengenai data restoran dapat dimanfaatkan untuk penggalian data menggunakan teknik data mining. Informasi yang dapat digali dari data restoran adalah pengelompokan kategori restoran berdasarkan jumlah menu yang terdapat pada restoran tersebut. Penelitian ini menerapkan teknik data mining menggunakan metode clustering partitioning around medoids ( $k$-medoids) untuk menghasilkan informasi mengenai pengelompokkan kategori restoran. Algoritma clustering Partitioning Around Medoids(PAM) atau disebut juga $K$-Medoids adalah algoritma untuk menemukan k cluster dalam n objek dengan pertama kali secara arbitrarily menemukan wakil dari objek (medoid) untuk tiap-tiap cluster. Pengelompokan dalam penelitian ini adalah appetizer, soup, main course, dessert, minuman dan snack. Kemudian hasil tersebut dapat dijadikan bahan atau dasar dari konsumen untuk memilih restoran berdasarkan kategori apa yang ingin konsumen makan. Berdasarkan data yang diperoleh, dihasilkan cluster yang merepresentasikan appetizer (cluster_2) 17 item, soup (cluster_1) 7 item, main course (cluster_4) 51 item, dessert (cluster_3) 11 item, minuman (cluster_5) 6 item dan snack (cluster_0) 13 item.
\end{abstract}

Kata kunci: Data Mining, $K$ - Medoids, Clustering

\section{IMPLEMENTATION OF PARTITIONING ALGORITHM AROUND MEDOIDS IN CLUSTERING RESTAURANT}

\begin{abstract}
The amount of data that is only limited to providing graphs or statistics regarding restaurant data can be used for data mining using data mining techniques. The information that can be extracted from restaurant data is the grouping of restaurant categories based on the number of menus in the restaurant. This study applies data mining techniques using clustering partitioning around medoids (k-medoids) to generate information about grouping restaurant categories. The clustering algorithm for Partitioning Around Medoids (PAM) or also known as KMedoids is an algorithm for finding $k$ clusters in $n$ objects by arbitrarily finding the representative of the object (medoid) for each cluster. The grouping in this research is appetizer, soup, main course, dessert, drink and snack. Then these results can be used as ingredients or the basis for consumers to choose a restaurant based on what category consumers want to eat. Based on the data obtained, a cluster is produced that represents an appetizer (cluster_2) 17 items, soup (cluster_1) 7 items, main course (cluster_4) 51 items, dessert (cluster_3) 11 items, drinks (cluster_5) 6 items and snacks (cluster_0) 13 item.
\end{abstract}

Keywords: Data Mining, $K$ - Medoids, Clustering

\section{PENDAHULUAN}

Keanekaragaman makanan khas pada suatu daerah membuat banyak para wisatawan lokal maupun luar daerah berkunjung untuk menikmati wisata kuliner (Benny, 2014). Banyaknya data rumah makan dapat dimanfaatkan untuk menjadi sebuah informasi yang dapat digali. Salah satu teknik yang mampu menggali informasi tersembunyi dari kumpulan data multidimensi yang telah diperoleh adalah teknik data mining. Salah satu teknik data mining yang cukup terkenal yaitu clustering.
Clustering adalah metode yang digunakan dalam data mining yang cara kerjanya mencari dan mengelompokkan data yang mempunyai kemiripan karakteristik antara data satu dengan data lainnya yang telah diperoleh (Ong dkk., 2013).

Metode ini dikembangkan dengan menentukkan struktur pengelompokkan diantara objek yang akan dikelompokkan. Analisis cluster dimulai dari metode hierarchical yang secara garis besar membentuk sebuah tree diagram yang biasa disebut dengan dendogram yang mendeskripsikan pengelompokan 
berdasarkan jarak, graph-theoritic melihat objek sebagai node pada network terboboti, mixture models mengasumsikan suatu objek dihasilkan dari skala data yang berbeda-beda, partitional lebih dikenal dengan metode non-hierarchy termasuk didalamnya adalah metode K-Medoids cluster. Algoritma clustering Partitioning Around Medoids(PAM) atau disebut juga $K$-Medoids adalah algoritma untuk menemukan k cluster dalam n objek dengan pertama kali secara arbitrarily menemukan wakil dari objek (medoid) untuk tiap-tiap cluster (Velmurugan, 2010)

Pada penelitian ini, algoritma Partitioning Around Medoids digunakan dalam pengelompokan rumah makan berdasarkan kriteria menu yang terdapat pada restoran tersebut. Pengelompokkan dibagi menjadi 6 cluster yaitu appetizer, soup, main course, dessert, minuman dan snack.

\section{METODE}

\subsection{Metode Pengumpulan dan Analisis Data}

Dalam kegiatan pengumpulan data untuk penelitian ini digunakan metode pengumpulan studi pustaka yang mana pada metode ini kegiatan dilakukan adalah mempelajari, mencari dan mengumpulkan data yang berhubungan dengan penelitian ini. Data yang digunakan dalam pengelompokkan restoran diperoleh dari observasi dan wawancara langsung dengan pemilik restoran. Sedangkan studi pustaka dengan cara mengumpulkan literatur pendukung penelitian, baik dari buku referensi maupun dari internet.

Data penelitian yang digunakan untuk penelitian adalah data restoran yang terdapat di Kota Semarang sebanyak 105 data.

\subsection{Algoritma clustering Partitioning Around Medoids}

Pada umumnya kinerja metode Algoritma clustering Partitioning Around Medoids secara berurutan adalah sebagai berikut :

1. Tentukan $k$ (jumlah cluster) yang diinginkan

2. Pilih secara acak medoid awal sebanyak $k$ dari $n$ data

3. Hitung jarak masing-masing obyek ke medoid sementara, kemudian tandai jarak terdekat obyek ke medoid dan hitung totalnya.

4. Lakukan iterasi medoid

5. Hitung total simpangan $\begin{array}{r}\text { (S) } \\ \text { Jika a adalah jumlah jarak terdekat }\end{array}$ antara obyek ke medoid awal, dan $\mathrm{b}$ adalah jumlah jarak terdekat antara obyek ke medoid baru, maka total simpangan adalah $\mathrm{S}=\mathrm{b}-\mathrm{a}$ Jika $S<0$, maka tukar obyek dengan data untuk membentuk sekumpulan $k$ baru sebagai medoid
6. Ulangi langkah 3 sampai 5 dan hentikan jika sudah tidak terjadi perubahan anggota medoid

\section{HASIL DAN PEMBAHASAN}

\subsection{Sample Data}

Data penelitian yang diperoleh dari observasi dan wawancara restoran di Kota Semarang kemudian diolah dengan cara difilter hanya untuk restoran yang memiliki menu makanan khas dan dihitung jumlah menu pada setiap kategorinya, sehingga dapat digunakan untuk clustering. Dari hasil pengolahan data, diperoleh data restoran yang memiliki makanan khas di Kota Semarang sebanyak 105 data yang akan dikelompokkan ke dalam enam cluster yaitu appetizer, soup, main course, dessert, minuman dan snack. Pengelompokkan tersebut berdasarkan atribut jumlah menu yang tersedia pada restoran tersebut, yang kemudian atribut tersebut akan diolah menggunakan algoritma Partitioning Around Medoids.

\begin{tabular}{|c|c|c|c|c|c|c|}
\hline \multirow{2}{*}{$\begin{array}{c}\text { Nama } \\
\text { Restoran }\end{array}$} & \multicolumn{6}{|c|}{ Jumlah Menu } \\
\hline & $\begin{array}{c}\text { Appeti } \\
\text {-zer }\end{array}$ & Soup & $\begin{array}{c}\text { Main } \\
\text { Course }\end{array}$ & Dessert & Snack & Drink \\
\hline $\begin{array}{l}\text { Bandeng } \\
\text { juwana }\end{array}$ & 4 & 0 & 8 & 1 & 10 & 0 \\
\hline $\begin{array}{l}\text { Elrina } \\
\text { Pandanaran } \\
\text { bandeng } \\
\text { presto }\end{array}$ & 0 & 0 & 2 & 0 & 0 & 0 \\
\hline $\begin{array}{l}\text { Bandeng } \\
\text { presto } \\
\text { bonafide } \\
\text { bandeng }\end{array}$ & 5 & 0 & 3 & 0 & 2 & 0 \\
\hline $\begin{array}{l}\text { presto } \\
\text { gemari } \\
\text { bandeng }\end{array}$ & 0 & 0 & 2 & 0 & 0 & 0 \\
\hline $\begin{array}{l}\text { presto } \\
\text { kampoeng } \\
\text { semarang } \\
\text { bandeng }\end{array}$ & 0 & 0 & 1 & 0 & 0 & 0 \\
\hline $\begin{array}{l}\text { presto } \\
\text { suyudono }\end{array}$ & 0 & 0 & 2 & 0 & 0 & 0 \\
\hline $\begin{array}{l}\text { Excellent } \\
\text { Bakery }\end{array}$ & 0 & 0 & 0 & 9 & 0 & 0 \\
\hline Hineni & & & & & & \\
\hline $\begin{array}{l}\text { Spesial } \\
\text { gongso }\end{array}$ & 0 & 0 & 4 & 0 & 0 & 0 \\
\hline $\begin{array}{l}\text { Jamu Jun } \\
\text { Lamper }\end{array}$ & 0 & 0 & 0 & 0 & 0 & 9 \\
\hline
\end{tabular}

\subsection{Implementasi Sistem}

Pada penelitian ini menggunakan tool rapid miner. Berikut adalah pengolahan data dengan menggunakan k-medoids pada rapid miner. Sample data yang digunakan dapat dilihat pada Gambar 1 . 


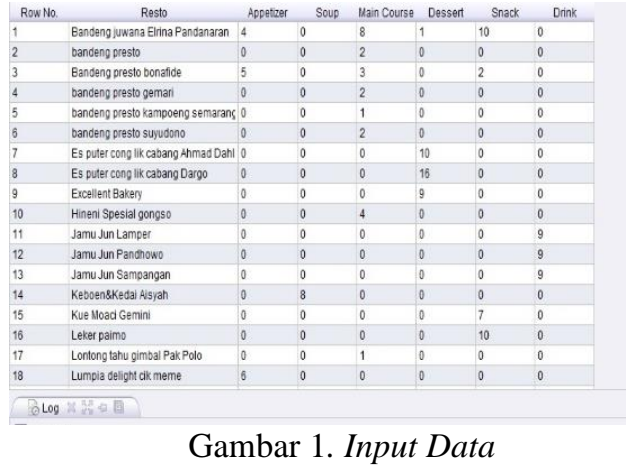

Dalam pemrosesan pemodelan Clustering $K$ Medoids pada Rapid Miner dapat dilihat pada Gambar 2 .

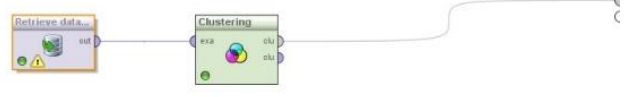

Gambar 2. Pemodelan Clustering K-Medoids pada Rapid Miner

Dengan menggunakan pemodelan $k$-medoids clustering seperti gambar 1 diatas, dengan inisialisasi jumlah cluster sebanyak enam buah, maka didapatkan hasil cluster yang terbentuk adalah enam, sesuai dengan pendefinisian nilai $\mathrm{k}$ dengan jumlah setiap cluster dengan total 105 data sebagai berikut :

1. cluster_ $0=13$ items

2. cluster_ $1=7$ items

3. cluster_ $2=17$ items

4. cluster_3 $=11$ items

5. cluster $4=51$ items

6. cluster_5 $=6$ items

Data hasil clustering pada rapid miner dapat dilihat pada gambar 3 .

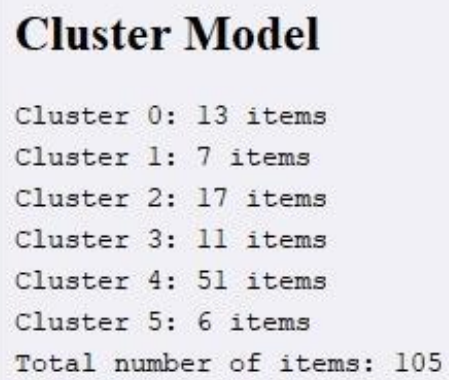

Gambar 3. Hasil Clustering

Hasil perhitungan antara jarak cluster dan centroid menggunakan k-medoids dapat dilihat pada gambar 4 .

\begin{tabular}{|l|l|l|l|l|l|l|}
\multicolumn{1}{|c}{ Attribute } & cluster_0 & cluster_1 & cluster_2 & cluster_3 & cluster_4 & cluster_5 \\
\hline Resto & 103 & 93 & 88 & 104 & 79 & 96 \\
\hline Appetizer & 0 & 0 & 8 & 0 & 0 & 0 \\
\hline Soup & 0 & 8 & 0 & 0 & 0 & 0 \\
\hline Main Cours & 0 & 0 & 0 & 0 & 6 & 0 \\
\hline Dessert & 0 & 0 & 0 & 9 & 0 & 0 \\
\hline Snack & 10 & 0 & 0 & 0 & 0 & 0 \\
\hline Drink & 0 & 0 & 0 & 0 & 0 & 9 \\
\hline
\end{tabular}

Gambar 4. Hasil perhitungan antara jarak cluster dan centroid

Hasil root cluster pada clustering $k$-medoids menggunakan rapid miner dapat dilihat pada gambar 5.

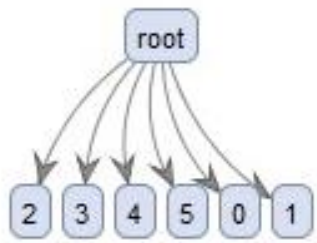

Gambar 5. Hasil root cluster

Grafik hasil data cluster dapat dilihat pada gambar 6.

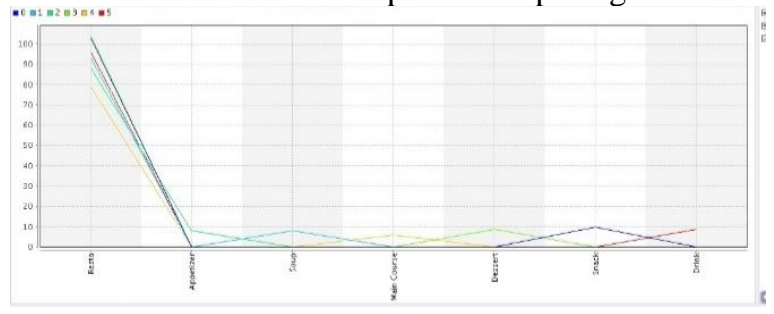

Gambar 6 Grafik data hasil Clustering K-Medoids

\section{KESIMPULAN DAN SARAN}

\subsection{Kesimpulan}

Tumpukan data restoran dapat digunakan untuk menentukan konsistensi data kategori menggunakan teknik data mining yang mampu menggali informasi tersembunyi dari kumpulan data multidimensi yang telah diperoleh, selain itu pengekstrakan data yang terhubung dengan data lain juga dapat dilakukan oleh teknik data mining ini. Salah satu teknik data mining yang cukup terkenal yaitu clustering dan metode yang cukup populer dalam teknik data mining ini adalah metode k-medoids. Partitioning around medoids $(P A M)$ atau lebih dikenal dengan algoritma $k$ Medoids merupakan salah satu algoritma clustering data mining. Dengan data uji berupa jumlah menu yang telah dikelompokan kedalam kategori jenis makanan sehingga dapat menghasilkan kategori dari sebuah restoran sebanyak 105 data, dihasilkan cluster yang merepresentasikan appetizer (cluster_2) 17 items, soup (cluster_1) 7 items, main course (cluster_4) 51 items, dessert (cluster_3) 11 items, minuman (cluster_5) 6 items dan snack (cluster_0) 13 items. Algoritma $k$-medoids telah bekerja dengan baik untuk menentukan setiap objek pada dataset pada setiap cluster. Berdasarkan uraian masalah di atas, maka dapat dirumuskan kesimpulan inisialisasi 
jumlah cluster sebanyak enam buah sesuai dengan pendefinisian nilai $\mathrm{k}$.

\subsection{Saran}

Penelitian ini dapat dikembangkan menjadi aplikasi maupun dibuat menggunakan bahasa pemrograman. Pengembangan penelitian selanjutnya dapat dikembangkan menggunakan perbandingan algoritma lainnya. Pada Penelitian ini, data yang digunakan hanya data restoran yang memiliki makanan khas, pada penelitian selanjutnya dapat dikembangkan jumlah data yang digunakan lebih secara luas.

\section{DAFTAR PUSTAKA}

A. K. Wardhani, "Implementasi Algoritma K-Means untuk Pengelompokkan Penyakit Pasien pada Puskesmas Kajen Pekalongan," J. Transform., vol. 14, no. 1, pp. 30-37, 2016.

T. Velmurugan, "Efficiency of k-Means and KMedoids Algorithms for Clustering Arbitrary DataPoints," International Journal Computer Technology \& Applications, vol. 3, 2012.

A. K. Wardhani, C. E. Widodo, J. E. Suseno, "Information System for Culinary Product Selection Using Clustering K-Means and Weighted Product Method," Proc. Atlantis Press Vol.165, pp.18-22, July 2018.

Raval, R. U., dan Chaita, J., Implementing and Improvisation of K-means Clustering Algorithm, International Journal of Computer Science and Mobile Computing, vol 5, hal 191-203, 2016.

Zhang, C., dan Fang, Z., An improved k-means clustering algorithm, Journal of Information and Computational Science, Vol 10, hal 193-199, 2013,

A. K. Wardhani, "Penerapan Algoritma Partitioning Around Medoids Untuk Menentukan Kelompok Penyakit Pasien(Studi Kasus : Puskesmas Kajen Pekalongan), Jurnal Kilat, Vol. 6, no 1, pp. 6-10, 2017.

Zheng Y., dan Qian Li., Density k-means: a new algorithm for centers initialization for $\mathrm{k}$ means, IEEE, hal 958-961, 2015.

X. Wu, V. Kumar, J.R. Quinlan, J. Ghosh, Q. Yang, H. Motoda, G.J. Mclachlan, A. Ng, B. Liu, P.S. Yu, Z.Z. Michael, S. David, and J.H. Dan, "Top 10 algorithms in data mining," Knowledge and Information Systems, 2008. 